Intisari Sains Medis 2021, Volume 12, Number 3: 978-980

P-ISSN: 2503-3638, E-ISSN: 2089-9084

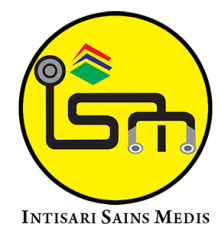

Published by Intisari Sains Medis

\section{Satu kasus langka: harlequin ichthyosis}

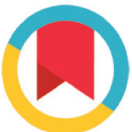

CrossMark

\author{
I Gusti Ayu Sattwika Pramita ${ }^{1 *}$, Ni Luh Putu Ratih Vibriyanti Karna ${ }^{2}$
}

\section{ABSTRACT}

Introduction: Harlequin ichthyosis is a genetic skin disease due to mutations in the ABCA12 gene inherited in an autosomal recessive manner. It is a severe form of ichthyosis characterized by a distinct clinical appearance of a thick stratum corneum. Harlequin ichthyosis is rarely found, and patients generally die a few days after birth.

Case description: We reported a baby girl aged one day with thick and cracked skin since birth. Physical examination revealed eclabium, ectropion, microtia, hyperflexion of the arms and legs, and hypoplasia of the fingers and toes. Dermatological examination showed thick yellowish-white scales separated by deep and erythematous fissures. The patient was placed in an incubator and was given supportive care, including nutrition and fluid through an orogastric tube, oleum olivarum as a moisturizer, gentamicin cream $0.1 \%$, and gentamicin eye ointment $0.3 \%$. The patient died after 21 days of treatment.

Conclusion: Harlequin ichthyosis has a poor prognosis and a high mortality rate due to impaired skin barrier functions that lead to dehydration, impaired thermoregulation, respiratory problems, and infections. Management of harlequin ichthyosis needs a multidisciplinary team and supportive care, consisting of fluid, electrolyte, and nutrition management, maintaining skin hydration, eye care, and preventing respiratory failure or sepsis.

Keywords: harlequin ichthyosis, autosomal recessive, skin disorder, ichthyosis, genodermatosis.

Cite This Article: Pramita, I.G.A.S., Karna, N.L.P.R.V. 2021. Satu kasus langka: harlequin ichthyosis. Intisari Sains Medis 12(3): 978-980. D0l: 10.15562/ism.v12i3.1024

\title{
ABSTRAK
}

Pendahuluan: Harlequin ichthyosis adalah penyakit kulit genetik yang diturunkan secara resesif autosomal dan merupakan bentuk berat dari iktiosis akibat adanya mutasi pada gen $A B C A 12$. Penyakit ini ditandai dengan adanya gambaran klinis yang khas berupa penebalan stratum korneum. Harlequin ichthyosis jarang ditemukan dan umumnya pasien meninggal beberapa hari setelah kelahiran.

Kasus: Dilaporkan seorang bayi perempuan berumur 1 hari dengan keluhan kulit tebal dan pecah-pecah sejak lahir. Pada pemeriksaan fisik ditemukan eklabium, ektropion, mikrotia, hiperfleksi lengan dan kaki, serta hipoplasia jari-jari tangan dan kaki. Berdasarkan pemeriksaan status dermatologikus didapatkan skuama tebal berwarna putih kekuningan yang dipisahkan fisura. Pasien diberikan perawatan suportif

Kata kunci: genodermatosis, harlequin ichthyosis, iktiosis, penyakit kulit, resesif autosomal.

Sitasi Artikel ini: Pramita, I.G.A.S., Karna, N.L.P.R.V. 2021. Satu kasus langka: harlequin ichthyosis. Intisari Sains Medis 12(3): 978-980. D0I: 10.15562/ism.v12i3.1024 berupa perawatan dalam inkubator, pemberian nutrisi melalui OGT, pelembab topikal oleum olivarum, antibiotik topikal gentamisin krim 0,1\%, dan salep mata gentamisin 0,3\%. Pasien meninggal setelah perawatan selama 21 hari.

Simpulan: Harlequin ichthyosis memiliki prognosis yang buruk dan angka kematian yang tinggi akibat gangguan dari barier kulit yang menyebabkan dehidrasi, gangguan termoregulasi, gangguan nafas dan infeksi. Penatalaksanaan pasien harlequin ichthyosis adalah multidisiplin dan bersifat suportif, terdiri atas manajemen cairan dan elektrolit, perawatan secara intensif dalam inkubator, pemberian nutrisi, menjaga hidrasi kulit, perawatan mata, dan pencegahan terjadinya gangguan napas, atau sepsis.

Sanglah, Denpasar, Bali, Indonesia;

igasattwikapramita@gmail.com

Diterima: 09-04-2021

Diterbitkan: 30-12-2021 


\section{PENDAHULUAN}

Harlequin ichthyosis adalah penyakit kulit yang diturunkan secara genetik (genodermatosis) secara resesif autosomal dan merupakan bentuk berat dari iktiosis yang jarang terjadi. Insiden harlequin ichthyosis sekitar satu per 300.000 kelahiran. ${ }^{1}$

Penyakit ini ditandai oleh penebalan stratum korneum sehingga bayi tampak terbungkus oleh membran tebal serta dapat ditemukan abnormalitas sistem organ lain seperti ekteropion, eklabium, telinga rudimenter, dan hipoplasia jari tangan. Diagnosis harlequin ichthyosis ditegakkan berdasarkan gambaran klinis yang patognomonik, pemeriksaan histopatologi, dan analisa genetik dengan ditemukan adanya mutasi pada gen ABCA12. ${ }^{2}$

Harlequin ichthyosis seringkali menyebabkan kematian dalam beberapa hari setelah kelahiran. Kulit yang tebal membatasi pergerakan anggota badan dan rongga dada sehingga menyebabkan kegagalan pernapasan dan sirkulasi. Bayi berisiko tinggi mengalami ketidakseimbangan elektrolit, dehidrasi, dan infeksi kulit yang dapat menyebabkan kematian. ${ }^{3}$

Prinsip penatalaksanaan harlequin ichthyosis berupa terapi suportif, terdiri atas manajemen cairan, elektrolit, dan nutrisi, obat-obatan topikal untuk hidrasi kulit berupa emolien yang mengandung bahan keratolitik, serta pencegahan infeksi. ${ }^{4}$

\section{LAPORAN KASUS}

Seorang bayi perempuan, berusia 1 hari, Warga Negara Indonesia, suku NTB, datang ke Rumah Sakit Umum Pusat Sanglah dengan keluhan kulit yang pecahpecah pada seluruh tubuh. Bayi adalah anak pertama, lahir melalui persalinan normal, aterm, usia gestasi 37-38 minggu, dengan berat badan 2.900 gram, panjang badan $49 \mathrm{~cm}$, nilai APGAR 7-8, dilahirkan oleh seorang ibu berusia 37 tahun. Selama hamil ibu hanya minum vitamin untuk kehamilan. Tidak ditemukan riwayat sakit, minum jamu atau obat-obatan selama hamil.

Kulit tebal dan pecah-pecah telah muncul sejak pasien lahir. Pada beberapa tempat, kulit yang pecah dan mengelupas menyebabkan luka. Keluhan kulit tersebut juga disertai kelopak mata yang terlipat keluar sehingga pasien sulit untuk menutup mata, bibir tampak tebal, telinga berukuran kecil, dan jari tangan serta kaki yang tidak terbentuk sempurna.

Riwayat penyakit dalam keluarga tidak ditemukan penyakit kulit ataupun penyakit genetik lainnya. Pada riwayat keluarga ditemukan riwayat kawin sedarah pada kedua orang tua pasien.

Pemeriksaan fisik pasien didapatkan kesadaran kompos mentis, nadi 144 kali/menit, frekuensi nafas 30 kali/ menit, dan temperatur aksila $37,2^{\circ} \mathrm{C}$. Pada status generalis didapatkan kepala mikrosefali, mata tampak ektropion, bibir tampak eklabium, dan telinga mikrotia. Ekstrimitas atas dan bawah tampak dalam posisi fleksi dan terdapat malformasi akral berupa jari tangan dan kaki yang tidak terbentuk sempurna.

Status dermatologis di seluruh tubuh didapatkan skuama tebal, berwarna putih kekuningan, melekat erat dengan bentuk mosaik yang terpisah oleh fisura. Di beberapa tempat tampak erosi multipel, bentuk geografika dengan ukuran bervariasi.

Pasien didiagnosis dengan harlequin ichthyosis. Penatalaksanaan yang diberikan kepada pasien berupa perawatan dalam kotak inkubator, pemberian cairan 60 $\mathrm{ml} / \mathrm{kg} /$ hari dan ASI dengan Orogastric Tube $22 \mathrm{ml}$ tiap 3 jam, pemberian oleum olivarum tiap 12 jam, dan gentamisin krim $1 \%$ tiap 12 jam topikal pada daerah erosi, serta mandi dengan sabun bayi. Pasien dikonsulkan ke bagian mata dan diberikan tatalaksana gentamisin $0,3 \%$ eye ointment tiap 8 jam. Pada hari perawatan ke-21 di Pediatric Intensive Care Unit (PICU)

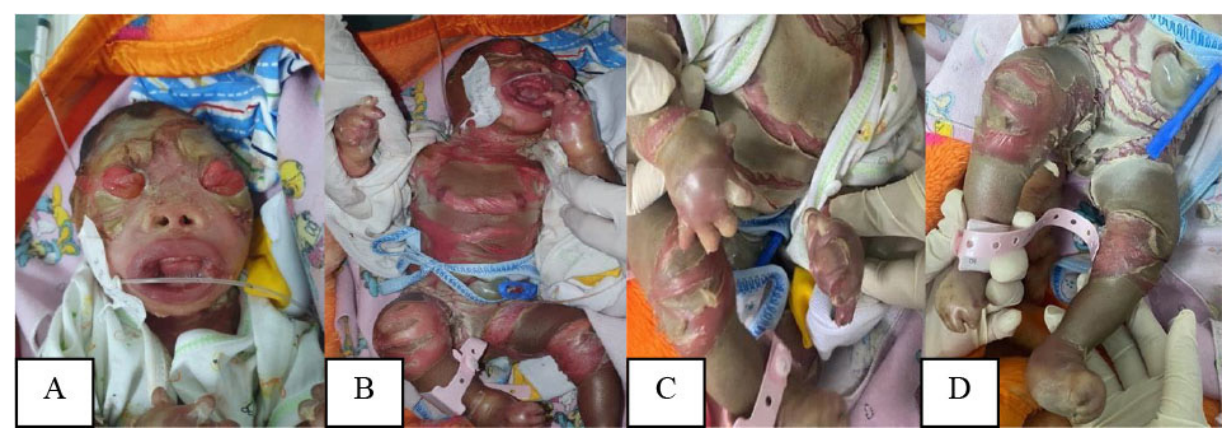

Gambar 1. Tampak ekteropion dan eklabium (A). Tampak skuama tebal, berwarna putih kekuningan dengan bentuk mosaik yang terpisah oleh fisura (B-C). keadaan pasien memburuk dan pasien meninggal.

\section{PEMBAHASAN}

Harlequin ichthyosis merupakan bagian dari Autosomal recessive congenital ichthyosis (ARCI). Risiko munculnya penyakit ini dari kedua orang tua pembawa gen resesif autosom sebesar 25\%. Harlequin ichthyosis terjadi akibat mutasi gen ABCA12 yang mengkode adenosine triphos-phate (ATP)-binding cassette (ABC) dalam sekresi granul lamelar pada stratum granulosum kulit dan transpor lipid epidermal sehingga menyebabkan gangguan transportasi lipid granul lamelar di bagian atas sel epidermis yang mengakibatkan malformasi lapisan lipid interseluler dari stratum korneum. ${ }^{3}$

Gambaran klinis harlequin ichthyosis berupa kulit tebal dan kaku berwarna kuning kecoklatan yang menunjukkan hiperkeratosis, melekat erat meliputi seluruh tubuh sehingga membatasi pergerakan. Kulit dipisahkan oleh fisura kemerahan yang dalam sehingga membentuk pola geometrik (diamond shaped) atau kostum Harlequin. Terdapat gangguan pembentukan telinga, kelopak mata ektropion dan bibir eklabium. Tangan dan kaki mengalami edema, terbungkus membran mukoid, dan ditemukan juga hipoplasia jari-jari. ${ }^{1,2}$

Pada kasus didapatkan kulit hiperkeratosis yang berbentuk mosaik dengan fisura dan erosi berbentuk geografika dengan ukuran bervariasi. Didapatkan juga eklabium, ektropion, mikrotia, hiperfleksi lengan dan kaki serta hipoplasia jari-jari tangan dan kaki yang sesuai dengan gambaran klinis harlequin ichthyosis. Adanya riwayat kawin sedarah 
pada kedua orang tua pasien juga menunjang diagnosis pada pasien, hal ini sesuai dengan insiden harlequin ichthyosis yang meningkat bila terdapat hubungan konsanguinitas.

Pemeriksaan penunjang yang mendukung diagnosis harlequin ichthyosis yaitu pemeriksaan histopatologik dengan gambaran ortokeratotik atau parakeratotik pada stratum korneum serta gambaran ultrastruktur berupa hilangnya badan lamelar pada stratum granulosum dan lamela lipid ekstrasel. Pemeriksaan genetik digunakan untuk menentukan gen yang mengalami mutasi. Pemeriksaan prenatal dengan dengan ultrasonografi, chorionic villus sampling dan amniosentesis dapat dilakukan untuk membantu diagnosis harlequin ichthyosis sebelum bayi lahir. ${ }^{5}$ Pada kasus ditegakkan diagnosis kerja harlequin ichthyosis berdasarkan atas anamnesis dan gambaran klinis yang patognomonik. Pemeriksaan histopatologis tidak dilakukan pada kasus.

Penatalaksanaan pasien harlequin ichthyosis bersifat suportif, terdiri atas manajemen cairan dan elektrolit, perawatan intensif dalam inkubator, pemberian nutrisi, menjaga hidrasi kulit, memantau suhu tubuh, perawatan mata, dan pencegahan terjadinya gangguan napas, atau sepsis. ${ }^{5,6}$ Pada kasus adanya kulit yang tebal dan mengelupas akan meningkatkan kehilangan cairan melalui kulit, eklabium juga menyebabkan kesulitan dalam proses makan dan minum sehingga pasien diberikan terapi suportif berupa pemberian cairan dan nutrisi melalui orogastric tube untuk mencukupi kebutuhan nutrisi pasien dan mencegah dehidrasi, perawatan dalam inkubator untuk menjaga suhu tubuh dan pelembab topikal. Pelembab dapat menjaga kulit tetap lembut, kenyal dan terhidrasi. Mandi dan berendam dapat mengurangi risiko infeksi kulit, melembabkan kulit dan melepaskan stratum korneum yang tebal. ${ }^{4,6}$ Pada kasus pelembab yang diberikan berupa emolien oleum olivarum yang bekerja dengan mengisi celah pada kulit sehingga dapat melembutkan dan meningkatkan elastisitas kulit, selain itu emolien juga membuat lapisan di permukaan kulit yang akan mengurangi penguapan cairan melalui kulit.

Antibiotik topikal diberikan pada daerah yang kulitnya mengelupas untuk mencegah infeksi sekunder. Terapi sistemik berupa retinoid oral tidak dapat diberikan kepada pasien karena ketidaktersediaan obat dan keterbatasan biaya orang tua. Ektropion yang didapatkan pada kasus dikonsulkan ke bagian mata agar mendapatkan perawatan untuk mencegah terjadinya keratitis / kerusakan kornea. Perawatan mata yang diberikan oleh bagian mata adalah salep antibiotik gentamisin. Konseling genetik diberikan kepada keluarga pasien mengenai kemungkinan terjadinya kembali harlequin ichthyosis pada kehamilan berikutnya.

Prognosis penyakit ini sangat buruk, sebagian besar pasien meninggal pada 3 hari pertama setelah dilahirkan. Bayi dengan harlequin ichthyosis rentan terhadap infeksi, kesulitan bernafas karena restriksi otot dinding dada yang mengakibatkan hipoventilasi dan gagal nafas, dehidrasi akibat kehilangan cairan tubuh, serta gangguan regulasi suhu tubuh yang menyebabkan ketidakseimbangan elektrolit. Kematian banyak disebabkan karena sepsis dan gangguan pada respirasi. ${ }^{3,7}$ Pada kasus, pasien meninggal setelah mendapatkan perawatan selama 21 hari yang kemungkinan disebabkan oleh gagal nafas, sepsis, dan dehidrasi sebagai komplikasi dari harlequin ichthyosis.

\section{SIMPULAN}

Dilaporkan suatukasus harlequinichthyosis pada seorang bayi perempuan usia 1 hari. Diagnosis ditegakkan berdasarkan anamnesis dan pemeriksaan fisik berupa skuama tebal berwarna putih kekuningan yang berbentuk mosaik, ektropion kedua mata, eklabium, dan mikrotia. Penatalaksanaan pada pasien berupa pemberian cairan dan menjaga suhu tetap hangat, pemberian emolien oleum olivarum, antibiotik topikal gentamisin krim 0,1 \%, dan salep mata gentamisin $0,3 \%$. Prognosis pada penderita adalah ad malam.

\section{KONFLIK KEPENTINGAN}

Penulis menyatakan tidak ada konflik kepentingan terkait publikasi laporan kasus ini.

\section{PERSETUJUAN ETIK}

Ibu pasien telah mendapatkan informed consent menyetujui informasi dan fotografi medis pasien digunakan dalam kepentingan publikasi dan edukasi pada bidang kedokteran.

\section{PENDANAAN}

Tidak ada.

\section{KONTRIBUSI PENULIS}

Seluruh penulis berkontribusi terhadap pemeriksaan, penyusunan naskah, dan publikasi laporan kasus ini.

\section{DAFTAR PUSTAKA}

1. Sharma DML. Harlequin Ichthyosis: Case Report of a rare disorder and Stigma attached to it. J Med Sci Clin Res. 2017;05(06):22910-4.

2. Mithwani AA, Hashmi A, Shahnawaz S, Al Ghamdi Y. Harlequin ichthyosis: a case report of prolonged survival. BMJ Case Rep. 2014;2014:bcr2013200884.

3. Akiyama M. Harlequin ichthyosis and other autosomal recessive congenital ichthyoses: The underlying genetic defects and pathomechanisms. J Dermatol Sci. 2006;42(2):83-9.

4. Mazereeuw-Hautier J, Hernández-Martín A, O'Toole EA, Bygum A, Amaro C, Aldwin M, et al. Management of congenital ichthyoses: European guidelines of care, part two. Br J Dermatol. 2018;180(3):484-95

5. Glick JB, Craiglow BG, Choate KA, Kato $\mathrm{H}$, Fleming RE, Siegfried E, et al. Improved Management of Harlequin Ichthyosis With Advances in Neonatal Intensive Care. Pediatrics. 2016;139(1):e20161003.

6. Oji V, Preil M-L, Kleinow B, Wehr G, Fischer J, Hennies HC, et al. S1 guidelines for the diagnosis and treatment of ichthyoses update. JDDG J der Dtsch Dermatologischen Gesellschaft. 2017;15(10):1053-65.

7. Jagadeesan S, Dayavannavar V, Veerappa S, Aisha A. Ichthyosis congenita, harlequin type: A case report and a brief review of literature. Indian J Paediatr Dermatology. 2016;17(4):319.

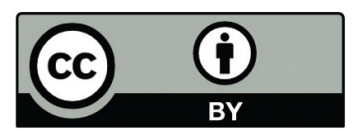

This work is licensed under a Creative Commons Attribution 